\title{
Inclusion and Participation: Working with the Tensions
}

\author{
GIDEON CALDER \\ School of Health \& Social Sciences, University of Wales, United Kingdom
}

\begin{abstract}
Democracy is crucially about inclusion: a theory of democracy must account for who is to be included in the democratic process, how, and on what terms. Inclusion, if conceived democratically, is fraught with tensions. This article identifies three such tensions, arising respectively in: (i) the inauguration of the democratic public; (ii) enabling equal participation; and (iii) the relationship between instrumental and non-instrumental accounts of democracy's value. In each case, I argue, rather than seeking somehow to dissolve or avoid such tensions, theories of democracy should allow us to live with their implications reflexively: to work with them. Such tensions are counter-democratic to the extent that they derail what Nancy Fraser calls "participatory parity," under which citizens count as "full partners in social interaction." But the extent to which they do this is not itself dependent on points of paradox in the very idea of inclusion. Such parity relies on complex factors, social and economic, which democratic institutions and procedures will not by themselves address. To achieve full democratic inclusion we must already have addressed such factors; no account of democracy itself, however finely-tuned, will do this.
\end{abstract}

\section{Introduction}

Any theory of democracy relies, somehow and at some or other point, on a theory of inclusion. We need to know who are to be included as participants in the democratic process, how, and on what terms. This applies wherever the "bar" is set, whether in terms of optimal or of realistic levels of democratic participation. So while the need to think through inclusion may seem especially acute when it comes to theories with a strong participative, deliberative or associative ${ }^{1}$ flavour-for example, the ever-more detailed articulations of the practical contours of deliberative democracy (see Elstub, 2010) - it also applies to those with a more minimalist, Schumpeterian "take" on the realistic parameters of democratic involvement. For Schumpeter (1942), famously, the "classical" notion wherein democracy entails that the citizenry in general should take a central participatory and decision-making role is misplaced and far-fetched. Rather, "the role of the people is to produce a government" (p. 269) and then to be governed by them. In modern democracies the agenda-setting initiative lies, as for Schumpeter it should,

Correspondence Address: Gideon Calder, Faculty of Education and Social Sciences, University of Wales, Newport, Caerleon Campus, Lodge Road, Newport NP18 3QT, United Kingdom. Tel.: +44 (0) 1633 432093; IM: Twitter: @gideoncalder

ISSN: $1911-4788$ 
with the candidates competing for leadership (p. 282), rather than with "the people" in some prior way. But even here, in the midst of a model of democracy entailing the very minimum of citizenly input and involvement, questions of inclusion arise. Even a not-much-involved citizenry requires that boundaries be drawn, and exclusions made, if it is to be identified or established as such. ${ }^{2}$ And that is the business of a theory of inclusion.

But the stakes are high. If the terms of inclusion are too "thick"- too prescriptive, or too presumptive about what counts as "good enough" participation-then they can be readily contested as prejudicial, bossily essentialist, arbitrary, blind to their own partiality or just plain oppressive. Too much thickness can seem, quite specifically, undemocratic, by placing too much decision-making weight on the side of prior criteria. By the time the process gets going, this may have disenfranchised the participants themselves, by trammelling their engagements within overly prescriptive rules about what kinds of contribution might be admissible or reasonable. But if the terms of inclusion are too "thin"-nonprescriptive, and easy-going about what counts as "good enough" participationthen they risk lapsing into self-undermining relativism. If anything goes when it comes to participation, then the case in question ceases to amount to any recommendation of democratic inclusion at all. To be democratic, inclusion will have conditions. Participation will have strings attached. The more assertive a democratic theory is about the value of participation, the less neutral it will be about how its participants participate. Indeed, on these terms one of the putative purposes of democracy - and for theorists such as John Stuart Mill, the key one-is to "promote the virtue and intelligence of the people themselves" (Mill, 1991, p. 226). Naturally, the promotion itself should be carried out in a democratic way.

And yet, just placing those last two sentences one after the other highlights how uneasily the two aims sit together, and how freighted with tensions they seem. On the one hand, participation in democratic life offers a means to an end presented as independently good: the development of the citizenry, the "promotion of their virtue and intelligence" or an equivalent goal. On the other hand, participation in democratic life is something the ends of which surely should be decided by the citizens themselves. Is their participation somehow inevitably virtue-promoting, however it goes and whatever they decide? How can we know this, if democratic life is open-ended, its course decided by those participating? In this article I want to unpack a cluster of issues surrounding democratic inclusion and participation, each in this general vein, and to suggest that the ambiguities encountered are both highly stubborn (if not inevitable) and yet also productive.

Rather than seeking somehow to dissolve or avoid them, theories of democracy should help us figure out how to live with such tensions reflexively-to work with them, as one might put it, rather than against them. I shall address each example of a tension with explicitly participative accounts of democracy as a reference point. This is not to suggest that such theories are somehow especially problematic, as models of democracy go: indeed, as may be clear from what follows, participative theories seem to me the strongest available. In fact, the reason for focusing on them is the other way around. Because such theories (should) confront questions of inclusion and participation in the fullest, broadest way, it is primarily with them

Studies in Social Justice, Volume 5, Issue 2, 2011 
(rather than with more minimalist stances) in mind that this article's points are made.

For my purposes here, deliberative and associative conceptions of democracy come under the general heading of participative theories, - even allowing for the complex, and in many ways separate, conceptual baggage of each term. A participative theory is one committed to a model of democracy requiring the promotion of broader and deeper participation in public decision-making. Participative theories address questions around the nuances of inclusion which would otherwise be neglected, but are nonetheless crucial for any theory of democracy. Even so, the questions still niggle at and disrupt our understanding of what democratic life amounts to. In Participation and Democratic Theory, Carole Pateman identifies the distinguishing features of participative theories this way:

The theory of participatory democracy is built round the central assertion that individuals and their institutions cannot be considered in isolation from one another... "[P]articipation" refers to (equal) participation in the making of decisions, and "political equality' refers to equality of power in determining the outcome of decisions. ... One might characterise the participatory model as one where maximum input (participation) is required and where output includes not just policies (decisions) but also the development of the social and political capacities of each individual, so that there is "feedback" from output to input. (Pateman, 1970, pp. 42-43)

Pateman has in mind particular strains of democratic theory emerging in the work of thinkers such as Rousseau, Mill and G. D. H. Cole. At stake here, though, are not the details of that trajectory but the markers of participative theories of democracy picked out in the quoted passage. We can rephrase them in terms of three focal points: (i) that the nature and degree of individuals' participation is crucial to what constitutes democracy (and democracy is about the relationship between institutions and individuals); (ii) that democratic participation requires political equality; and (iii) that the outputs of democracy should include not just decisions, but also individual development. The next three sections address tensions attaching to each of these points in turn. The purpose of so doing is not to theorize inclusion itself in any extended way, but to reinforce its centrality and, at the same time, the stubborn and demanding nature of the tensions it brings.

Some view such tensions in an apocalyptic way. From this point of view, either they must be resolved, or we must accept a certain untenability about democracy both in ideal and real terms. Noticeably, this point of view is often shared by those keenest to diagnose this untenability and those keenest to avert it. My argument is that accepting the tensions points, instead, in a different kind of direction. It is not the job of democracy to resolve tensions, but to help us elaborate them. If we expect it somehow to sort out all of the conflicts to which it gives rise, then we will have set it an impossible task. Delivering consensus and frictionless consolidation of shared values cannot be part of the project. But on the other hand, for such tensions to be workable with and liveable with, social and economic justice must be tackled first, or at least simultaneously. In other words, the tensions I discuss are pernicious to the extent that society is characterized by structural inequalities and benign to the extent that they are not. In so arguing, I am insisting on a certain priority of political economy over democracy - or at the very least, that the two should be addressed at once. 


\section{Tension 1: Getting Inclusion Started}

One tension about inclusion concerns the way in which the democratic public is inaugurated. The tension can be couched in stronger or more muted ways. Stella Gaon (2009) presents it as a kind of transcendental instability inherent in the very idea of democracy "both as an idea and as a form of political regime ... democracy is essentially impossible as a legitimate form of rule, because the very constitution of the 'people' that embodies sovereignty cannot itself be democratically or legitimately established" (p. 1).

In its more muted sense, this impossibility might be rendered instead as a troublesome lacuna. Thus Gaon herself cites Sophia Näsström (2003), who identifies a "gap at the heart of democracy in the sense that 'the people'-in order to constitute the legitimate source of political authority-would have to be prior to itself" (p. 808). Whether or not this makes democracy impossible in any a priori way, it seems to make achieving it difficult. If democracy is - point (i) - about the relationship between individuals and their institutions, rather than just a matter of constructing the institutional machine in the right way, then we will wonder about how the right relationship between individuals and their institutions comes into being, given that both, strictly speaking, must be instituted at once. Specifically, we shall wonder how their coming into being can itself be democratic. This is mundanely true in a practical-historical sense: decisions about the terms of any actually existing democracy cannot themselves have stemmed from democratic processes of decision-making.

Now of course, democracy such as we have it did not emerge fully formed and already democratically accounted for. Rather, it has evolved in a messy, impure way. The phrasing of Gaon and Näsström is chronologically purist, however: it assumes that for democratic processes to be possible, their inauguration must itself be democratic, so that democracy must pre-exist itself. In a way this view is curiously ahistorical, insofar as nothing ever comes into being as some kind of perfect mirror of this or that abstracted political theory. Even so the point bites hard at the level of ideal theory, and in particular at the point of legitimacy: just because at this level we find people talking precisely as if the purist model can and should obtain. Joshua Cohen (2003), for instance, refers to all forms of democracy when specifying that the "fundamental idea of democratic legitimacy is that the authorisation to exercise state power must arise from the collective decisions of the members of a society who are governed by that power" (p. 17). If so, how does legitimacy, or the authorization to exercise state power, get started? As I have put it elsewhere:

Should we democratically figure out how democratic procedures will work, who is included in "the people," and so on? If not, democracy seems to begin from somewhere non-democratic, which sounds troubling, and perhaps self-undermining. But if the terms of democracy themselves are to spring from some prior democratic conversation, we confront some hefty paradoxes. Who constitutes the "we" who decides the boundaries of the "we"? Which people decide who is to be included under the heading of "the people"? Which voices pronounce on whose voices are to count? (Calder, 2011b, p. 126) 
It seems too that these questions translate from an ideal register to a more practical one. Even if the paradoxes they pick out do not render democracy inevitably irretrievable from its impure origins, they certainly pose it problems.

These problems themselves are especially acute when it comes to the extension of participation, especially if along with Pateman, we insist on the inseparability of individuals and institutions. Both people and processes will "do the work" in extending the range of those included. Across a wide range of actually existing democratic contexts, the terms of inclusion will be imposed by the "includers" rather than the "includees," and will pre-date the transition towards inclusion itself. In other words, to be included is, at least to this extent, to be assimilated (with individuals and institutions) rather than consulted on the terms of inclusion. To demonstrate one's credentials is to adapt to terms into the formation of which one has had no input. Includees, in this sense, may be incomers: migrants, and others new or marginal in the demos. They may also be those to whom participation rights are extended, through for example the lowering of the minimum age for participation. But equally, they might be those living within the demos who are deemed to be insufficiently participative-whose contributions as active citizens are lacking: the socially excluded or those deemed to be under-contributing economically. The UK government's drive to combat "social exclusion" in the years following the election of the Blair government in 1997 is emblematic of such projects of (social, rather than specifically political) inclusion.

A hallmark of the various initiatives pursued under this heading-such as "welfare to work," embodied in the New Deal-was a combination of rhetoric about social inclusion through enhanced participation with coercive pre-formed agendas based on "thick" notions of "appropriate behaviour," typically identifying citizenship with economic contribution (Levitas, 2005, especially ch. 8) and stipulating a range of conditions to fit. Thus, participation was installed as an independent good, an outcome to be pursued through economic levers of a more or less coercive nature. In other words, it was to be achieved non-participativelywithout the includees being party to the process through which the terms of participation were developed. This is hardly an exceptional occurrence; what would be exceptional would be any example of a policy purportedly aimed at widening participation which itself was negotiated and rolled out along the lines of democratic participation.

Social inclusion in the New Labour sense is not, primarily, centred on the promotion of democracy. But as an example it highlights how closely the promotion of participation might sit to induced compliance with a pre-formed agenda. Recall Cohen, on the fundamentals of democratic legitimacy: "the authorisation to exercise state power must arise from the collective decisions of the members of a society who are governed by that power" (Cohen, 2003, p. 17). Whoever they are, the non-participative sectors of society have, by definition, not contributed to any collective decision by which they are then directed, and to which they are bound. This point would apply under any model of democracy. If we adopt a participative model, and so are serious about (i) "that the nature and degree of individuals' participation is crucial to what constitutes democracy"- then the point is reinforced and deepened. Is participation in collective decision-making a prerequisite for democratic legitimacy? If so, any project designed to extend inclusion is hit by the kinds of chicken-and-egg problem we have been discussing. 


\section{Tension 2: The Paradox of Enablement}

Point (ii) above states that "democratic participation requires political equality." In Participation and Democratic Theory, Pateman has her own take on the particular significance for democracy of social and economic equality, with workers' participation in industry taken as a priority. But virtually all theories of democracy side with Elizabeth Anderson, in claiming that (something like) what she calls "equality of social relations"" is a core value of democratic life:

By equality I do not mean that everyone enjoys equal esteem or reputation, or equally good jobs or income, nor that everyone is equal in virtue or merit. Democratic equality rather denotes a kind of standing in civil society to make claims on others, that they respect one's rights, pay due regard to one's interests, and include one as a full participant in civil society. . . Everyone counts, and everyone counts equally. (Anderson, 2009, p. 219)

Formal acknowledgement that democracy depends upon such equality is one thing. What would be required to attain it is another question. Still another question, and equally pressing, is what forms of social norms of democratic interaction might actually serve to reinforce the equal standing of citizens - and whether any society has, in practice, hit upon such norms. On the theory side, of course, we find different ways of thinking through the democracy/equality relation.

Among the most powerful recent articulations of the tightness of fit between equal standing and democracy is Nancy Fraser's account of inclusion, exemplified in turn in her conception of "participatory parity." This figures not as part of a theory of democracy per se, but as a democratic theory of social justice. Fraser (2003) seeks to identify "social arrangements that permit all (adult) members of society to interact with one another as peers" (p. 36). Parity means "the condition of being a peer, of being on a par with others, of standing on an equal footing" (p. 101 n. 39); it is dependent on institutions according people "the status of full partners in social interaction" (p. 229). The moral requirement is that "members of society be offered the possibility of parity, if and when they choose to participate in a given activity or interaction" (p. 101 n. 39). Fraser's version of a response to tension 1 thus seems to be this: for any decision or event to be truly participative, it must offer the possibility of peerhood to those who sign up. This does not resolve the chronological lacuna: they cannot already have been involved in deciding the terms of whatever it is that they are participating in. But given that lacuna, Fraser's response provides a way of proceeding. We ensure that a realistic offer of the possibility of parity is part and parcel of informed involvement with any activity or interaction: thus the norms of participation are reflexively inclusive. We do not know in advance what substantive shape they will take. This shape will be determined-deliberatively elaborated and thrashed out-by the participants themselves.

Yet as I have argued at greater length elsewhere (Calder, 2010) this very point signals a circularity problem with Fraser's account, and more generally with the relationship between equal standing and participation in decision-making, - one which gives a partial echo of tension 1. Kevin Olson helps pin it down: participatory parity "presupposes equal agency at the same time that it seeks to 
promote it" (Olson, 2008, p. 261). Participation is the means by which claims to justice will be raised, and thus itself is a kind of enabler of parity: it affords citizens not currently treated as peers the scope to argue for context-sensitive policies which will (as Fraser puts it above) "represent a step in the direction of parity." But here an irony emerges. Olson sets it out like this:

The people who most need to make claims about injustice, those who are politically disadvantaged in a given society, are the ones whose participatory parity is most at risk. They are most in need of parity-promoting policies. By definition, though, people who cannot participate as peers are precisely the ones least capable of making such claims. The problem, in short, is that deliberation presupposes participatory parity at the same time that deliberation is supposed to set the standards for participatory parity. (Olson, 2003, pp. 260-261)

Olson calls this circularity "the paradox of enablement." It occurs when "equally able citizens are both presupposed by deliberation and are its intended product" (2003, p. XX). Hence the echo of tension 1.

To sum up the paradox of enablement: standards concerning what it is to participate, to be a peer, to attain Fraser's version of what Anderson calls equal standing are themselves something to be produced through the participatory process. For participatory parity to be duly democratic, such norms cannot pre-date the process, but are engendered by it. They emerge out of deliberations among the citizenry, rather than being pre-ordained. But for participatory parity to obtain at the point of deliberation, we must presuppose equal agency in the processes through which it is formulated. Inclusion, as it were, needs to be prior to itself for the process to work in the way Fraser expects of it. The voices of the marginalized seem thereby to be rendered inadmissible. They will not be heard, simply because they are not already equipped to participate on an equal footing, vis-à-vis (for example) what J.L. Austin (1962) called the "illocutionary force" of speech-actstheir capacity to successfully perform an action. ${ }^{3}$ And such problems are starkest when they serve to prevent people from making claims about their own exclusion. Here "marginalization is not simply a violation of parity. It additionally deprives people of the means to demand inclusion" (Olson, 2008, p. 262).

Tension 2 is thus a more specifically located version of tension 1 . The latter concerns the apparent impossibility of getting democratic processes started in a democratic way. The former centres on the need to presuppose as a prerequisite of democratic processes something which seems more accurately depicted as one of their possible outcomes: democratic agency. One way of avoiding the tension would be to remove what counts as equal standing, or participatory parity, from the subject-matter of democratic decision-making, and to define these in prior, nonnegotiable terms. But this places an extraordinarily heavy epistemic and normative burden on any such prior definition. It must somehow define equality of standing in such a way that it is definitively non-exclusionary. It must account for in advanceor at least allow space for addressing - all the ways in which citizens might contingently be deprived of equal standing, by dint of social structure, patterns of discrimination or disrespect, disregard for individual or group interests and so on. The history of the politics of inclusion suggests that struggles against oppressionalong lines of class, gender, ethnicity, disability and otherwise-depend vitally on the space to challenge preconceptions about what counts as counting equally. When 
such challenges come off, it is not just stances hostile to egalitarian challenges to the status quo which are required to adjust themselves in response, but understandings of equality itself, from among its own strongest proponents. Thus versions of equal standing and democratic agency are what are achieved by such struggles. To put it no more subtly than this: if equal standing and democratic agency were already there, the struggles would not be needed.

\section{Tension 3: Instrumental vs. Non-Instrumental Value}

Our third point above-(iii) that the outputs of democracy should include not just decisions, but also individual development-reflects not just the terms of democracy, but its ultimate justification. It invokes a well-worn conflict which comes in different forms, often and problematically elided. One version of the conflict is well characterized by Anderson's (2009) contrast between instrumental and non-instrumental accounts of democracy's value. For instrumental accounts,

the purpose of government, like that of the market, is to satisfy individual preferences. Individual preferences are assumed to be formed exogenously to democratic processes. Democratic mechanisms of accountability are instituted to ensure that the government tries to satisfy those preferences. (p. 213)

And-glossing Anderson's (2009) own rendering of the contrast-for an account to be non-instrumental to any degree, it simply has to insist that there is a value to democracy which is not reducible to the satisfaction of separately formed individual preferences, even if "its non-instrumental value is conditional on its instrumental value" (p. 213).

Another version of the conflict is captured by the contrast between "outcomebased" and "process-based," or between "substantive" and "procedural" accounts of value. ${ }^{4}$ For outcome-based and substantive accounts, value resides in what is delivered by any given system, institution or programme. For process-based and procedural accounts, value resides in how the delivery takes place. Combined focus on the "what" and the "how" is not necessarily untenable. Fraser, for example, argues that participatory parity is both an "outcome notion" and a "process notion," insofar as it both makes the achievement of parity of participation a necessary condition of any justifiable social arrangement, but asserts too that norms are legitimate "if and only if they can command the assent of all concerned in fair and open processes of deliberation" (Fraser, 2008, p. 29). But the basic contrast holds, and is captured neatly by a slight corruption of Herbert Simon (though see also Ceva and Calder, 2009): the substantively valuable is that which "is appropriate to the achievement of given goals within the limits imposed by given conditions and constraints," and the procedurally valuable is that which "is the outcome of appropriate deliberation" (Simon, 1979, pp. 67, 68).

Point (iii) seems clearly aligned with the outcome-based/substantive sides of these contrastive pairs. If we suggest that the outputs of democracy should include $x$, then this departs from purely non-instrumental and procedural models. On any account, democracy will have outputs, and these will include decisions. But if one argues, in a "thicker" way, that democracy's value lies in its capacity to generate 
"good" decisions (so that if another system generated better decisions, it would to that extent be preferable) then one is subscribing to a justification of democracy which is both instrumental (to the extent that democracy is a means to an end) and substantive (to the extent that the end in question is conceived as valuable in itself). And if, with Mill, we regard individual development as one of the ends of democracy, then our commitments become thicker still: not just epistemic (vis-àvis what counts as a good decision) but also ontological (vis-à-vis what, in the way of impacts on the individual, counts as "developmental" rather than regressive). But it's worth noting that this does not necessarily point in the direction of instrumentality as characterised by Anderson. Neither good decisions nor individual development equate with the satisfaction of exogenously-formed individual preferences. In fact, a rejection of instrumentalism couched in these terms is perfectly compatible with a substantivist/outcome-based account of democracy's value. The substantivist is, as such, no more necessarily committed to a market-style understanding of the satisfactions delivered by democracy than the subscriber to the cliché that "the proof of the pudding is in the eating" is committed to the promotion of tiramisu. What the substantivist is committed to is the claim that in the end, democracy is justified by its achievement of certain goals. It is perfectly consistent with this to offer an account of those goals in non- or antimarket terms.

Nonetheless, a tension remains here. I would put it in these terms. Democracy's value is not pure, in the sense of neatly occupying one or other side of these divides. Rather, it is ambivalent between them, in ways that mirror Fraser's own depiction of "participatory parity." Even a case - as I myself would favourarguing that accounts of democracy's value will inevitably be substantive does not, ipso facto, commit itself to any claim that democracy has no procedural value, or that procedures are not necessary to it or that as long as it delivers substantively valuable outcomes, the procedures have no value in themselves. To put it another way: either to fetishize the pristine value of the process regardless of its results, or to assume that democracy has no value except for its propensity to deliver $\mathrm{x}$, is misplaced. As if to epitomise the latter assumption, Shirley Letwin (1989) writes: "Would we want democracy if we had access to indisputable knowledge of what ought to be done? The answer is, of course, no" (p. 223). The "of course" here is eminently disputable. For to assert it is to assume both that the value of democracy is solely teleological, and that the telos of democracy is, solely, better knowledge. Substituting for "indisputable knowledge of what ought to be done" alternatives such as "failsafe conditions for social cohesion," "policies which would guarantee greater citizenly awareness of the views of others" or, indeed, Mill's "another, better way of promoting the virtue and intelligence of the people themselves" (Mill, 1991, p. 226) would be objectionable in just the same way. It is because democracy can tenably have no single telos that its value, inevitably, lies in part in the democratic process itself. To put this point in terms which may seem trite: an identifiable and distinctively democratic process is a necessary condition of the realization of the particular plurality of outcomes associated with democracy. It is because the process itself is not valuable unless it delivers various kinds of beneficial results (a necessary, but not sufficient condition) that convincing justifications of democracy will always be in part substantive. 


\section{Working with the Tensions}

Much contemporary discussion of democracy's potentials, limitations and rightful forms is dominated by a concern for difference, especially cultural difference. That is to say, it starts from the presumption that differences in cultural orientation and conceptions of the good will be characteristic of any genuinely democratic system. Different responses to this emerge across different areas of the literature, from Rawls's latter take on political liberalism (1993) through the more deliberative models of Habermas (e.g., 1995) and Benhabib (e.g., 1996) to Mouffe's agonistic alternative (e.g. 2000) and beyond, in subtle gradations and sophistications of these and similar positions. Sometimes this stems from more nuanced thinking about citizenship, its nature and its scope. In part it may stem too from what Richard Rorty (1998) diagnoses as the "culturalization" of progressive politics since the 1960 s, so that as it has grown ever more sensitive to questions of cultural difference, and less bothered about money - through a period in which, across the West, "economic inequality and economic insecurity have steadily increased" (Rorty, 1998, p. 83). In any case, it is characteristic of such literature to couch tensions in terms of the politics of difference. Something striking about the tensions identified above is that none of them are definitively of that register. They operate entirely separately from debates about multiculturalism, for example, and the typical dilemmas taken to arise therein. None of them requires circumstances of cultural diversity in order to "bite." They would be characteristic of the most culturally homogeneous polity, as much as of the most culturally heterogeneous one.

To make this point is not to downplay or sideline the importance of cultural diversity. Rather, it is to point out that analytically, these tensions arise elsewhere than in clashes between what Rawls (1993) depicts as "comprehensive" valuesdifferently held, metaphysically controversial understandings of the good. They are not, for example, doctrine-relative: they do not require for their emergence any particular bodies of belief, nor clashes between such bodies of belief. ${ }^{5}$ Rather they apply at a different level: the level at which the terms of inclusion and participation in democratic decision-making are to be conceptualised and justified per se. I have been suggesting that we are stuck with each tension; that it is a mistake to think that they can somehow be conceptualised away either in an ideal model or in the practice of democratic life. On the other hand, I have also been suggesting that this stubbornness need not be vicious; that we can work with tensions like these so that they need not jeopardise our seeking more genuinely inclusive and participative democratic practice. To make this case seems to me to require the assistance of two kinds of argument. One needs to show that it is not the purpose of democracy to resolve tensions - so that it is not threatening to democracy per se if it cannot so do. The other needs to acknowledge that these tensions can have unacceptably pernicious implications in practice-but to insist too that this is not a necessary feature, but something contingent on circumstances. In closing, I shall say a little more about each of these points in turn.

First: the point that these tensions are not necessarily pernicious. A certain exaggeration of the implications of issues of the type explored here is shared by those, like Gaon, who think they make democracy impossible and by those, like 
Rawls and Habermas, who think that democracy requires an identifiable dimension of (overlapping) consensus to guard against the potentially disruptive implications of difference. What is held in common is the assumption that such tensions threaten legitimate politics. Gaon's objections are versions of various standard qualms about the very notion of the social contract as the source of political legitimacy. Such a contract is, in a literal sense, impossible. It may arguably be impossible for conceptual reasons too-but it is certainly not the case that any conceivable political order will originate in the kind of founding consensual manoeuvre that the social contract would require as a historical event. This, of course, is why social contract theorists tend instead to characterise the contract in hypothetical or counterfactual terms. (If they were to find themselves in such a situation, what would be rational or fair in the terms to which would-be contractees might sign up?) But recourse to a level of consensus or "public reason" either definitively idealised (Habermas) or working as a kind of common denominator among ostensibly antagonistic conceptions of the good (Rawls) itself betrays an assumption that legitimate politics cannot tolerate tensions at a constitutive level.

This assumption, as Mouffe and others have sought to show, is eminently questionable. $^{6}$ If democracy is to amount to a system in which different positions, interests and perspectives find a voice, then to start from a position fearful of the tensions that might emerge is, to precisely this extent, to miss the point. Epistemically speaking, to assume that democracy must start with consensus-even at the most abstracted level-is to assume in advance something that only the interplay of arguments might reveal; namely that claims made in respect of a plurality of goods and values might converge. As John O'Neill (2007) has put it, the virtue of democracy may lie not its (putatively) resolving conflicts, but in its revealing them (p. 183). O'Neill makes this point with reference to participants in deliberative processes, as part of a case designed to disrupt the presumption that consensus will, or should, be the outcome of any such process. It might apply equally at the level at which the very terms on which inclusion and participation are conceived. Here too we find tensions. But if we conceive the epistemic benefits of democracy not simply in terms of delivering the truth, or of enhancing the pool of social knowledge, but (also) reflexively, in terms of the shedding of light on the terms of democracy itself, then the revelation of such tensions might itself be of value.

In other words: if the process of widening participation, or of addressing the terms of inclusion, exposes tensions inherent in such goals, then so much the better. It is better that we know about them, especially if (for partisan reasons) we are committed to including particular voices hitherto unheard. Working with democracy reveals dissonances, both between points of view, and in terms of the circumstances in which they emerge; it is better that we know about these than that we do not. It will not suit political parties, or other established interest groups, that it be widely known that the conditions of democracy itself are more unstable than the dominant ideology might suggest. But this is no reason not to expose the fact. The problem with Letwin's position, discussed earlier, is that it assumes that we already know what a good epistemic result is; a virtue of democracy, however, is that it enhances the scope for reflexivity about what itself counts as a good result.

Still, if there is always an epistemic value in such exposure, that is not to say that it is always conducive to sustaining a reflexive, engaged democratic life. Whether 
this is the case depends not on the terms of democracy itself, but on the way in which it sits vis-à-vis other considerations. Throughout this article, I have been working with the assumption that it is within participative conceptions of democracy, broadly construed, that the nuances and complexities of social dynamics are best revealed. But what those dynamics are will be only partially determined by the operations of democracy. Democracy works with what is given, by way of structural relations and the operations of power. It does not, by itself, control these or remove their harmful consequences. So if tensions obtain of the kind addressed here, whether or not they are pernicious depends on factors other than the simple terms of democratic engagement. It depends on the backdrop against which this engagement takes place. It is the degree of structural inequality - of economic resources - which is the most crucial aspect of this backdrop.

So my case is that while we find stubborn tensions in the very idea of inclusion, it is a piece of philosophical fetishism to insist that these, by themselves, will somehow render impossible the process of inclusion. Rather, the degree to which such tensions amount to impediments to something like democracy ensuing will depend on the structural features of the backdrop against which participation takes place. Such tensions are counter-democratic to the extent to which they derail what Fraser calls participatory parity. But the extent to which they derail this is not itself dependent on points of paradox in the very idea of inclusion. It depends on the socio-economic landscape. If a society is characterised by a long historic legacy of slavery, for example, or chasmic divides between rich and poor, or heavy gender oppression, then it is these factors which will make the tensions pernicious at the point at which there is an attempt to overcome them via democratic processes, rather than the conceptual dissonances inherent in ensuring inclusive participation. The paradox of enablement will not amount to a crisis of democracy in a society somehow, in some unlikely way, already characterised by an absence of relative poverty and a history of profound equality in terms of gender, race and disability. So if we consider this claim by Iris Young (2000, pp.5-6) - "The normative legitimacy of a democratic decision depends on the degree to which those affected by it have been included in the decision-making processes and have had the opportunity to influence the outcomes"-in terms of what must be the case in order for "those affected" to be genuinely "included," we shall always be talking about factors lying outside the terms of inclusion themselves. For those terms to work, and for inclusion to run its course, is not something that democracy can by itself ensure, necessary though it may be to this process of fruition. We must already have addressed, somehow, the terms on which individuals and groups are rendered excluded by factors other than the presence or absence of democratic engagement.

The case made in this article can be summed up like this. Democracy is crucially about inclusion. Inclusion, if conceived democratically, is fraught with tensions. These tensions are disruptive to democracy to the extent that inclusion is up against radical inequality and exclusion. The extent to which these characteristics are typical of the modern Western polity is a matter for another discussion. 


\section{Notes}

1 Elstub himself uses the term "associational" in depicting a democratic model in which voluntary associations located in civil society are key (Elstub, 2008, p. 101). Paul Hirst (1994) uses both "associative" and "associationalist" to denote something broadly equivalent.

2 Schumpeter himself acknowledges the inevitability of such discrimination, and argues that "disqualifications on grounds of economic status, religion and sex," or indeed race, are, in principle, no more incompatible with the democratic method than disqualifications on the basis of age (Schumpeter, 1942, pp. 244-245). This is not because he approves of such exclusions, but rather because of his view of the nature of democracy itself. Democracy is not a way of life (except for the leaders) but a method "for arriving at political decisions in which individuals acquire the power to decide by means of a competitive struggle for the people's vote" (p. 269). Such a definition is neutral with regard to the composition of the electorate; for it to work, it just requires that there is an electorate, marked out as such by some or other set of rules.

3 I am grateful to Keith Sutherland for suggesting the Austinian phrasing.

4 Still another, and also helpful, way of rendering the contrast comes with Ronald Dworkin's distinction between "dependent" and "detached" conceptions of the relation between democracy and equality. On the "dependent" view, "the main features of a democracy . . . are justified because [such] a community . . . is more likely to distribute material resources and other opportunities in an egalitarian way." For the "detached" approach, "we judge the fairness or democratic character of a political process by looking to features of that process alone, asking only whether it distributes political power in an equal way, not what results it promises to produce" (Dworkin, 2003, pp. 117118). The "dependent" view broadly corresponds to the "outcome-based," "substantive" and "instrumental" accounts of democracy's value sketched here, and the "detached" view to the "process-based," "procedural" and "non-instrumental" accounts. But the correspondences are loose, and - for reasons which I address below — not to be taken as implying any necessary incompatibility between stances falling in one column or the other.

5 For more on the notion of doctrine-relativity, though in a different context, see Calder (2011).

6 See Mouffe (2000) - but see also Noonan (2006) for a discussion of Mouffe's work on democracy which argues that she herself slips into many of the presumptions of the mainstream liberal and rationalist traditions which she critiques.

\section{References}

Anderson, E. (2009). Democracy: instrumental vs. non-instrumental value. In T. Christiano and J. Christman (Eds.), Contemporary debates in political philosophy (pp. 213-227). Oxford: WileyBlackwell.

Austin, J. L. (1962). How to do things with words. Oxford: Clarendon Press.

Benhabib, S. (1996). The deliberative moment and the problem of difference. In S. Benhabib (Ed.), Democracy and difference (pp. 3-18). Princeton: Princeton University Press.

Calder, G. (2010). Pragmatism, critical theory and democratic inclusion. Etica \& Politica 12(1), 52-67.

Calder, G. (2011a). Climate change and normativity: constructivism versus realism. Critical Review of International Social and Political Philosophy 14(2), 153-169.

Calder, G. (2011b). Democracy and listening. In M. Crumplin (Ed.), Problems of democracy: language and speaking (pp. 125-135). Oxford: Inter-Disciplinary Press.

Ceva, E., \& Calder, G. (2009). Values, diversity and the justification of EU institutions. Political Studies 57(4), 828-845.

Cohen, J. (2003). Procedure and substance in deliberative democracy. In T. Christiano (Ed.), Philosophy and democracy (pp. 17-38). Oxford: Oxford University Press.

Elstub, S. (2008). Towards a deliberative and associational democracy. Edinburgh: Edinburgh University Press.

Elstub, S. (2010). The third generation of deliberative democracy. Political Studies Review 8(3), 291307.

Fraser, N. (2003). Social justice in an age of identity politics. In N. Fraser \& A. Honneth, Redistribution or Recognition? (pp. 7-109) London: Verso.

Fraser, N. (2008) Scales of justice: reimagining political space in a globalising world. Cambridge: Polity Press. 


\section{Gideon Calder}

Gaon, S. (2009). Introduction. In S. Gaon (Ed.), Democracy in crisis: Violence, alterity, community (pp. 1-25). Manchester: Manchester University Press.

Habermas, J. (1995). Between facts and norms. Cambridge: Polity Press.

Hirst, P. (1994). Associative democracy. Cambridge: Polity Press.

Letwin, S. (1989). Democracy and the rule of law. In G. Brennan \& L. E. Lomasky (Eds.), Politics and process (pp. 221-234). Cambridge: Cambridge University Press.

Levitas, R. (2005). The inclusive society? Social exclusion and New Labour (2 ${ }^{\text {nd }}$ ed.). Houndmills: Palgrave.

Mill, J. S. (1991). On liberty and other essays. Ed. J. Gray. Oxford: Oxford University Press.

Mouffe, C. (2000). The democratic paradox. London: Verso.

Näsström, S. (2003). What globalization overshadows. Political Theory 31(6), 808-34.

Olson, K. (2008). Participatory parity and democratic justice. In N. Fraser (Ed.), Adding Insult to Injury (pp. 246-272). London: Verso.

O’Neill, J. (2007). Markets, deliberation and environment. London: Routledge.

Pateman, C. (1970). Participation and democratic theory. Oxford: Oxford University Press.

Rawls, J. (1993). Political liberalism. New York: Columbia University Press.

Rorty, R. (1998). Achieving our country: Leftist thought in twentieth-century America. Cambridge, MA: Harvard University Press.

Schumpeter, J. (1942). Capitalism, socialism and democracy. New York: Harper.

Simon, H. (1979). From substantive to procedural rationality. In F. Hahn \& M. Hollis (Eds.), Philosophy and Economic Theory (pp. 65-86). Oxford: Oxford University Press.

Young, I. M. (2000). Inclusion and democracy. Oxford: Oxford University Press. 